\title{
PENGARUH KESEIMBANGAN KEHIDUPAN KERJA, KEPRIBADIAN PROAKTIF, DAN KECERDASAN EMOSIONAL TERHADAP KEPUASAN KARIR
}

\author{
Syailendra Eka Saputra ${ }^{1)}$, Rizky Natassia ${ }^{2)}$ *, Hayu Yolanda Utami ${ }^{3)}$ \\ 1,2,3 Program Studi Pendidikan Ekonomi STKIP PGRI, Sumatera Barat, 2511, Indonesia. \\ E-mail: ${ }^{1}$ syailend_ra@yahoo.com, ${ }^{2}$ rizkynatassia@gmail.com, ${ }^{3}$ hayuyudha @ gmail.com
}

\begin{abstract}
Abstrak
Penelitian dilaksanakan untuk menganalisis pengaruh keseimbangan kehidupan kerja, kepribadian proaktif dan kecerdasan emosional terhadap kepuasan karir pegawai Sekretariat Daerah Kabupaten Pasaman. Pada penelitian ini digunakan beberapa pegawai untuk dijadikan sampel yang dilakukan dengan menggunakan metode sampel jenuh. Metode analisis yang digunakan dalam menjawab hipotesis adalah Ordinary Least Square (OLS). Hasil pengolahan data ditemukan bahwa keseimbangan kehidupan kerja dan kecerdasan emosional berpengaruh positif terhadap kepuasan karir yang dirasakan pegawai, sedangkan kepribadian proaktif tidak berpengaruh terhadap kepuasan karir yang dirasakan pegawai Sekretariatan Daerah Kabupaten Pasaman.
\end{abstract}

Kata Kunci: keseimbangan kehidupan kerja, kepribadian proaktif, kecerdasan emosional, kepuasan karir

\begin{abstract}
The study was conducted to analyze the effect of work-life balance, proactive personality, and emotional intelligence on career satisfaction of the Pasaman District Secretariat employees. In this study, several employees were used to be sampled by using the saturated sample method. The analytical method used in answering the hypothesis is Ordinary Least Square (OLS). The results of data processing found that work-life balance and emotional intelligence have a positive effect on career satisfaction felt by employees, while proactive personality has no effect on career satisfaction felt by employees of the Pasaman regency secretariat office.
\end{abstract}

Keywords: work life balance, proactive personality, emotional intelegence, career satisfaction 


\section{PENDAHULUAN}

Career satisfaction atau kepuasan karir menunjukkan pengalaman yang menyenangkan dalam bekerja karena bidang pekerjaan yang dilakukan sesuai dengan bakat, kompetensi, dan pengalaman (Srikanth dan Israel, 2012). Kepuasan karir juga dapat didefinisikan sebagai kesesuaian keinginan karyawan terhadap pencapaian karir yang mereka peroleh. Selain itu menurut Valentine, et. al., (2015) mengungkapkan kepuasan karir sebagai kesesuaian antara harapan atau keinginan pada saat bekerja dengan kenyataan yang dirasakan dan berhubungan dengan peningkatan karir atau kesuksesan seseorang dalam menjalankan karirnnya.

Kepuasan dalam berkarir menjadi keinginan setiap individu yang bekerja tidak terkecuali pada pegawai Sekretariat Daerah Kabupaten Pasaman. Instansi publik yang dikelola oleh pemerintah daerah tersebut menawarkan jenjang karir yang dapat diraih oleh masing-masing pegawai, tentunya proses untuk meraih jenjang karir yang lebih tinggi masing-masing pegawai harus dapat menunjukan dedikasi yang tinggi pada instansi dan tanggung jawab yang dimilikinya. Jika diamati dari struktur karir di dalam Sektariat Daerah terdapat beberapa pegawai yang jabatan karirnya tidak sejalan dengan masa mereka berkarir, sehingga kepuasan dalam berkarir yang terbentuk dalam diri pengawai relatif rendah.

Menurut Jawahar dan Liu (2016) tidak tercapainya keinginan yang dirasakan sejumlah individu dalam bekerja akan mempengaruhi psikologis mereka dalam melaksanakan tugas dan tanggung jawabnya. Pada umumnya individu yang memiliki kepuasan karir yang rendah akan melakukan berbagai perilaku kontraproduktif yang merugikan diri individu dan organisasi Oleh sebab itu untuk meningkatkan kepuasan karir diperlukan motivasi dan tekad yang kuat dalam diri individu yang bekerja (Joo dan Ready, 2012).

Menurut Luthans (2017), kepuasan berkarir yang dirasakan oleh masing-masing individu yang bekerja dapat dipengaruhi oleh sejumlah variabel diantaranya keseimbangan kehidupan kerja (work life balance) kepribadian proaktif dan kecerdasan emosional. Ketika seorang pegawai mampu menjaga keseimbangan antara kehidupan dunia dan rohaninya maka kepuasan berkarir akan meningkat, disamping itu ketika seorang pegawai memiliki kepribadian yang proaktif maka mereka akan mudah bergaul dan bekerja sama dengan individu lain dalam bekerja sehingga karir yang mereka peroleh akan cepat meningkat serta meningkatkan kepuasan berkarir. Sedangkan kecerdasan emosional akan membantu individu yang bekerja untuk menghadapi sejumlah permasalahan yang berkaitan dengan pekerjaan. Ketika kecerdasan emosional seorang pegawai semakin baik, maka pegawai tersebut akan semakin disukai baik oleh atasan atau pun rekan kerja, sehingga dapat menciptakan kepuasan berkarir yang lebih tinggi (Sony dan Mekoth, 2016).

Robbin dan Judge (2016), work life balance menunjukan perilaku psikologis seorang pegawai untuk dapat menjaga keseimbangan peran dalam melaksanakan tugas sebagai bagian dari organisasi atau peran mereka di dalam lingkungan keluarga. Menurut Qodrizana dan Musadieq (2018), ketika seorang pegawai dapat menciptakan keseimbangan antara peran mereka dalam organisasi dengan peran mereka dalam lingkungan keluarga maka keseimbangan kehidupan kerja akan terwujud. Ketika keseimbangan kehidupan kerja dirasakan 
karyawan maka akan menciptakan aman dan nyaman dalam bekerja sehingga dapat mendorong meningkatnya kepuasan berkarir.

Hasil penelitian yang dilakukan oleh Yusnani dan Prasetio (2018), menemukan keseimbangan dapat mendorong kepuasan karir pada karyawan perempuan. Hasil yang sejalan diperoleh oleh Neumann et. al. (2018) yang menemukan bahwa keseimbangan kehidupan kerja yang semakin tinggi dalam diri pegawai akan menciptakan rasa nyaman dan damai dalam bekerja, sehingga keberhasilan dalam bekerja menjadi terwujud, kondisi tersebut mendorong meningkatnya kepuasan yang dirasakan karyawan dalam berkair. Selanjutnya hasil Rondonuwu, et. al. (2018) serta penelitian Wallace (2015) menyatakan bahwa terjadi korelasi positif yang kuat antara keseimbangan kehidupan kerja dengan kepuasan karir yang dirasakan individu yang aktif bekerja.

Menurut Trivellas, et al. (2015), kepuasan karir akan selalu berubah sejalan dengan perubahan waktu. Salah satu faktor yang dapat memengaruhi kepuasan seseorang dalam berkarir adalah kepribadian proaktif yang dimiliki pegawai. Selanjutnya Jawahar dan Liu (2016), mengungkapkan kepribadian adalah nilai dasar yang menunjukan jati diri seseorang yang tergambar dari perilaku seseorang dalam kesehariannya termasuk juga di dalam bekerja. Seseorang yang memiliki keperibadian proaktif akan energik dan aktif dalam bekerja, seseorang yang memiliki kepribadian proaktif adalah seseorang yang pekerja keras dan pantang menyerah, sehingga wajar individu dengan kepribadian proaktif akan meraih kesuksesan dalam berkarir.

Sejumlah hasil penelitian yang membahas pengaruh kepribadian proaktif terhadap kepuasan berkarir telah dilakukan Jawahar dan Liu (2016) yang menemukan bahwa kepribadian proaktif berpengaruh terhadap kepuasan berkarir yang dirasakan pegawai. Hasil penelitian yang sejalan juga diperoleh oleh Li dan Yuan (2017) yang menemukan individu memiliki kepribadian proaktif dalam bekerja akan mendapatkan kesuksesan karir yang lebih tinggi sehingga mendorong meningkatnya kepuasan dalam berkarir. Selanjutnya, hasil penelitian yang dilakukan Ismasari (2016) mempertegas sejumlah hasil penelitian terdahulu yang menemukan kepribadian proaktif berkorelasi positif dengan kepuasan berkarir yang dirasakan pegawai.

Selain work life balance dan kepribadian proaktif menurut James et. al. (2015) mengungkapkan kepuasan dalam berkarir juga dapat dipengaruhi oleh kecerdasan emosional. Menurut Suryanti (2019), kecerdasan emosional sebagai kemampuan seseorang untuk mengendalikan diri secara emosional dalam berbagai lingkungan khususnya pada lingkungan kerja. Kemampuan seorang individu untuk mengendalikan emosinya dalam lingkungan kerja akan memudahkannya untuk beradaptasi dan menggapai kesuksesan dalam berkarir.

Hasil penelitian yang membahas pengaruh kecerdasan emosional terhadap kepuasan berkarir telah dilakukan oleh Sony dan Mekoth (2016) menemukan bahwa semakin baik kecerdasan emosional seseorang akan meningkatkan kepuasan karir pada pegawai perempuan. Temuan yang sama diperoleh Sultana, et. al. (2016), menemukan kemampuan mengelola emosi diri sejalan dengan peningkatan karir yang dirasakan seorang karyawan.

Selanjutnya, hasil penelitian yang dilakukan oleh Chen, et. al. (2020) yang mengungkapkan bahwa seseorang dengan 
kemampuan kecerdasan emosional yang baik akan dapat menyelesaikan pekerjaan dengan baik dan tepat kerena mereka mampu bekerja sama dengan rekan kerja dan cepat diterima dalam sebuah lingkungan pekerjaan. Selain itu, hasil penelitian Suryanti (2019) menemukan bahwa kecerdasan emosional berpengaruh positif terhadap kepuasan karir yang dirasakan karyawan.

\section{LANDASAN TEORI}

\section{Kepuasan Karir}

Kepuasan karir merupakan luapan emosional dari seseorang atas keberhasilan dirinya dalam mencapai kesuksesan selama bekerja (Luthans, 2017). Kepuasan karir juga dapat diamati dari kesuksesan demi kesuksesan yang diraih seorang individu dalam bekerja, dimana kesuksesan tersebut mendorong adanya pengakuan dari orang lain. Kepuasan berkarir juga menunjukan sejumlah kemajuan yang dirasakan individu dalam bekerja. Kemajuan tersebut telah menciptakan rasa bangga dan bahagia dalam bekerja (James, et al., 2015).

Selanjutnya, Robbin dan Judge (2016) mengungkapkan kepuasan karir yang dirasakan masing-masing individu relatif berbeda antara satu dengan yang lainnya. Kepuasan karir akan dapat diamati dari sejumlah kemajuan yang diraih oleh setiap individu dalam bekerja. Dengan demikian dapat disimpulkan bahwa kepuasan karir berkaitan dengan pencapaian yang diraih secara personal oleh setiap individu yang bekerja.

\section{Keseimbangan Kehidupan Kerja}

Keseimbangan kehidupan kerja dikatakan ketika seseorang yang bekerja mampu menjaga keseimbangan kewajiban di lingkungan kerja dengan kewajiban di lingkungan keluarga (Luthans, 2017). Keseimbangan kehidupan kerja akan menciptakan perasaan nyaman untuk terus bekerja. Kemampuan individu membagi waktu antara kewajiban atas pekerjaan dengan kewajiban keluarga menjadi kunci terbentuknya keseimbangan.

Rivai, dan Sagala (2016), menyatakan setiap individu yang bekerja sangat menyadari bahwa mereka miliki kewajiban ganda yang harus dikelola agar tidak menciptakan konflik. Ketika individu yang bekerja mampu membagi waktu dan mengelola pihak-pihak yang saling berkepentingan dengan baik maka keseimbangan kehidupan kerja akan dirasakan, sehingga akan menciptkan kebahagian serta mendorong kepuasan dalam bekerja.

\section{Kepribadian Proaktif}

Luthans (2017), mengungkapkan bahwa kepribadian merupakan karkteristik yang dimiliki setiap individu. Kepribadian tidak dibawa sejak lahir akan tetapi terbentuk karena adanya proses sosialisasi dan proses pembelajaran. Proses sosialisasi dilakukan dalam lingkungan keluarga, sedangkan proses pembelajaran dilakukan dalam lingkungan pendidikan.

Setiap individu memiliki kepribadian yang relatif berbeda-beda. Salah satu bentuk kepribadian yang dapat dimiliki oleh seseorang adalah kepribadian proaktif. Dalam konsep kepribadian proaktif, individu yang memilikinya akan terlihat sangat luwes dan aktif sehingga mereka sangat mungkin mendapatkan kesuksesan dalam bekerja (Robbin dan Judge, 2016). Kepribadian proaktif akan mendorong seseorang untuk memiliki sikap kerja yang positif, sehingga dapat memberikan kesuksesan dalam berkarir. 


\section{Kecerdasan Emosional}

Setiap individu memiliki tingkat kecerdasan yang berbeda beda baik secara emosional ataupun intelektual. Luthans (2017) menyatakan kecerdasan emosional berperan penting untuk menentukan kesuksesan seseorang dalam bekerja. Kecerdasan emosional menunjukan sejauhmana seseorang yang berada diberbagai lingkungan dapat mengendalikan emosi.

James, et. al. (2015) menyatakan kecerdasan emosional dapat terlihat dari perilaku seseorang baik di lingkungan masyarakat ataupun di lingkungan pekerjaan. Seseorang yang memiliki kecerdasan emosional yang tinggi akan sangat baik mengontrol emosi diri dan mudah beradaptasi pada berbagai lingkungan sehingga menjadi salah satu syarat terwujudnya kepuasan dalam berkarir.

\section{Pengembangan Hipotesis}

\section{Pengaruh Keseimbangan Kehidupan Kerja Terhadap Kepuasan Karir}

Karatepe, et. al. (2020), menemukan terjadi hubungan positif antara keseimbangan kehidupan kerja dengan kepuasan karir pada pegawai perempuan. Hasil penelitian yang dilakukan oleh Rondonuwu, et. al. (2018) juga menemukan bahwa keseimbangan kehidupan kerja berpengaruh positif terhadap kepuasan karir yang dirasakan karyawan Hotel Sintesa Penisula Menado.

Lalu, hasil penelitian Qodrizana dan Musadieq (2018) menemukan bahwa keseimbangan kehidupan kerja yang tinggi dalam diri pegawai akan menciptakan rasa nyaman dan damai dalam bekerja, sehingga keberhasilan dalam bekerja menjadi terwujud, kondisi tersebut mendorong meningkatnya kepuasan yang dirasakan karyawan dalam berkair. Kesuksesan yang diperoleh akan mendorong kenaikan karir yang tentunya akan menciptakan perasaan bangga dan bahagia dalam diri masing masing pegawai. Selanjutnya, hasil penelitian Yusnani dan Prasetio (2018) menyatakan bahwa keseimbangan pengelolaan kewajiban antara pekerjaan dan keluarga akan sejalan dengan rasa puas yang dirasakan pegawai dalam berkarir.

\section{Pengaruh Kepribadian Proaktif Terhadap Kepuasan Karir}

Hasil penelitian Jawahar dan Liu (2016) menyatakan kepribadian proaktif berpengaruh positif terhadap kepuasan karir seseorang. Ismasari (2016) juga mengungkapkan seseorang berkepribadian proaktif lebih besar kemungkinan untuk merasakan kepuasan karir dibandingkan individu lain dengan kepribadian lainnya.

Kesamaan hasil penelitian diperoleh Joo dan Ready (2012) yang menyatakan bahwa kepribadian proaktif akan mendorong meningkatnya kesuksesan seseorang dalam berkarir sekaligus meningkatkan kepuasan yang dirasakan pegawai dalam berkarir. Keberhasilan yang diperoleh akan meningkatkan nilai penghargaan dan pengakuan terhadap prestasi. Selanjutnya hasil penelitian yang dilakukan oleh Buil, et. al. (2019) mempertegas sejumlah hasil penelitian terdahulu yang menemukan kepribadian proaktif berkorelasi positif dengan kepuasan berkarir yang dirasakan pegawai.

\section{Pengaruh Kecerdasan Emosional Terhadap Kepuasan Karir}

Sultana, et. al., (2016) menyatakan kecerdasan emosional yang tinggi akan konsisten dengan rasa puas yang dirasakan 
individu dalam berkarir. Hal yang sama juga diperoleh dalam penelitian Sony dan Mekoth (2016) yang menemukan kecerdasan emosional yang dimiliki seseorang berpengaruh positif dengan kepuasan karir.

Karatepe, et. al. (2020) menemukan bahwa kecerdasan emosional berpengaruh positif terhadap kepuasan berkarir pada pegawai perempuan. Hasil penelitian yang sejalan juga diperoleh oleh Anda (2016) kecerdasan emosional dalam bekerja merupakan salah satu kunci untuk meningkatkan kepuasan karir. Selanjutnya, hasil penelitian yang dilakukan oleh Jensen, et. al. (2017) menyatakan seseorang dengan kemampuan kecerdasan emosional yang baik akan dapat menyelesaikan pekerjaan dengan baik dan tepat kerena mereka mampu bekerja sama dengan rekan kerja dan cepat diterima dalam sebuah lingkungan pekerjaan. Prestasi yang diraih karyawan akan menjadi sebuah kebanggaan, sedangkan reward yang diterima akan menciptakan kepuasan dalam berkarir.

\section{METODE}

Penelitian ini adalah penelitian kuantitatif karena bertujuan untuk membuktikan beberapa hipotesis melalui tahapan pengujian statistik yang direncanakan diolah melalui bantuan program SPSS. Objek penelitian yang digunakan adalah seluruh pegawai Kantor Sekretariatan Kebupaten Pasaman yang berjumlah 101 orang. Jumlah pegawai Kantor Sekretariatan Kabupaten Pasaman terlihat pada Tabel 1 dibawah ini:
Tabel 1

Unit Kerja Pegawai Kantor Sekretariatan Kabupaten Pasaman Tahun 2019

\begin{tabular}{lc}
\hline \multicolumn{1}{c}{ Bagian Penempatan } & $\begin{array}{c}\text { Jumlah } \\
\text { (Orang) }\end{array}$ \\
\hline Bagian Administrasi & 9 \\
Bagian Hukum dan HAM & 8 \\
Perekonomian dan Sumber Daya Alam & 8 \\
Bagian Administrasi Pembangunan & 7 \\
Bagian Pengadaan Barang dan Jasa & 11 \\
Bagian Kesejahteraan Rakyat & 8 \\
Bagian Umum & 33 \\
Bagian Organisasi & 8 \\
Bagian Protokol dan Komunikasi Pimpinan & 9 \\
\hline Jumlah & 101 \\
\hline
\end{tabular}

Sumber: data diolah (2019)

Proses pengumpulan data dan informasi dilakukan dengan menggunakan kuesioner penelitian. Metode analisis data yang digunakan untuk membuktikan kebenaran hipotesis dilakukan dengan analisis regresi berganda yang diolah dengan menggunakan bantuan program SPSS versi 25.0

\section{HASIL DAN PEMBAHASAN}

Sejalan dengan hasil pengolahan data, dapat dinarasikan demografis responden terlihat pada Tabel 2 dibawah ini:

Tabel 2

Demografis Responden

\begin{tabular}{lcc}
\hline \multicolumn{1}{c}{ Demografis } & Jumlah & Persentase \\
\hline Gender & & \\
Laki-Laki & 46 & 50.40 \\
Perempuan & 45 & 49.50 \\
\hline Umur & & \\
23 - 25 Tahun & 8 & 8.80 \\
26 - 30 Tahun & 15 & 16.50 \\
31 - 35 Tahun & 21 & 23.10 \\
36 - 40 Tahun & 37 & 40.70 \\
$>$ 40 Tahun & 10 & 11.00 \\
\hline Pendidikan & & \\
SMA & 6 & 6.60 \\
D3 & 17 & 18.70 \\
S1 & 17 & 18.70 \\
S2 & 37 & 40.70 \\
Lainnya & 14 & 15.40 \\
\hline Lama Bekerja & & \\
< 1 Tahun & 6 & 6.60 \\
1 - 5 Tahun & 40 & 44.00 \\
6 - 10 Tahun & 22 & 24.20 \\
> 10 Tahun & 23 & 23.30 \\
\hline Status di Pekerjaan & & \\
Menikah & 88 & 3.30 \\
Belum Menikah & 3100 \\
\hline & & \\
\hline
\end{tabular}

Sumber: data diolah (2019) 
Sejalan dengan Tabel 2, diketahui sebagian besar responden adalah laki laki yang mencapai $50.40 \%$ dari total responden, sedangkan sisanya sebesar 59,50\% lainnya adalah responden perempuan. Mengacu pada identifikasi data diketahui sebagian besar responden berusia antara 36 tahun sampai dengan 40 tahun, yaitu mencapai $40,79 \%$ dari total responden. Dengan demikian dapat disimpulkan pegawai Kantor Sekretariatan Kabupaten Pasaman didominasi oleh pegawai berusia dewasa.

Jika diamati dari kompetensi pendidikan terlihat sebagian besar pegawai berpendidikan setingkat $\mathrm{S} 2$, yaitu mencapai $40.70 \%$ sedangkan pegawai yang berpendidikan terendah adalah setingkat SMA. Selain itu, juga teridentifikasi sebagian besar pegawai memiliki masa kerja antara 1 tahun sampai dengan 5 tahun dan sebagian besar dari pegawai Kantor Sekretariatan Kabupaten Pasaman berstatus menikah.

\section{Hasil Pengujian Normalitas}

Sesuai dengan proses pengujian normalitas yang telah dilaksanakan diperoleh hasil terlihat pada Tabel 3 berikut:

Tabel 3 Hasil Pengujian Normalitas

\begin{tabular}{lccc}
\hline \multicolumn{1}{c}{ Variabel } & $\begin{array}{c}\text { Asymp Sig } \\
(\text { 2-Tailed })\end{array}$ & Std & Hasil \\
\hline Kepuasan Karir & 0.101 & 0.05 & Normi \\
Keseimbangan Kehidupan Kerja & 0.077 & 0.05 & Normi \\
Kepribadian Proaktif & 0.065 & 0.05 & Normi \\
Kecerdasan Emosional & 0.062 & 0.05 & Normi \\
\hline Sumber: data diolah (2019) & & &
\end{tabular}

Pada Tabel 3 terlihat bahwa masing masing variabel penelitian yang digunakan telah berdistribusi normal. Dengan demikian tahapan pengolahan data lebih lanjut dapat segera dilaksanakan.

\section{Pengujian Asumsi Klasik}

\section{Hasil Pengujian Multikolinearitas}

Mengacu pada tahapan pengolahan data yang telah dilakukan dengan menggunakan bantuan program SPSS diperoleh ringkasan hasil pengujian multikolinearitas terlihat pada Tabel 4 berikut:

Tabel 4

Hasil Pengujian Multikolinearitas

\begin{tabular}{|c|c|c|c|}
\hline Vzariabel & Tol & $V I F$ & Kesimpulan \\
\hline $\begin{array}{l}\text { Keseimbangan Kehidupan } \\
\text { Kerja }\end{array}$ & 0.562 & 2.862 & $\begin{array}{c}\text { Tidak } \\
\text { Terjadi }\end{array}$ \\
\hline Kepribadian Proaktif & 0.530 & 2.667 & $\begin{array}{l}\text { Tidak } \\
\text { Terjadi }\end{array}$ \\
\hline Kecerdasan Emosional & 0.569 & 2.928 & $\begin{array}{c}\text { Tidak } \\
\text { Terjadi }\end{array}$ \\
\hline
\end{tabular}

Sumber: data diolah (2019)

Pada Tabel 4 terlihat bahwa seluruh variabel independen yang akan dianalisis dalam sebuah model persamaan regresi berganda telah terbebas dari gejala multikolinearitas.

\section{Hasil Pengujian Heeroskedastisitas}

Proses atau prosedur pengujian ketiga adalah mendeteksi gejala heteroskedastisitas. Pengujian dilakukan dengan metode Scutterplot seperti terlihat pada Gambar 2 di bawah ini:

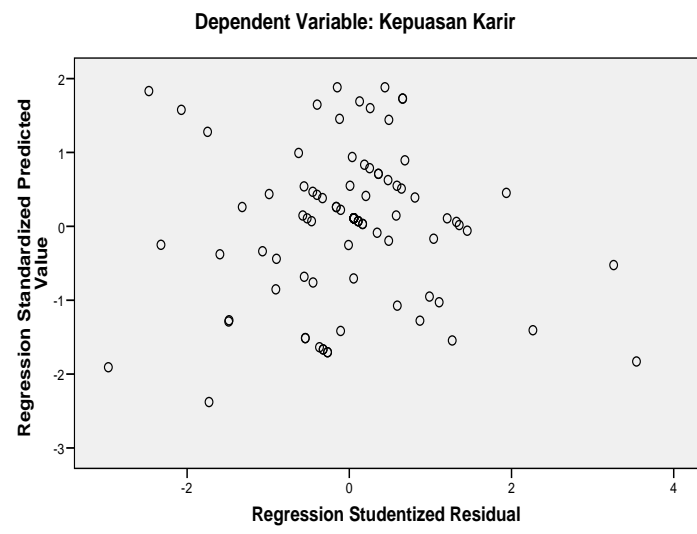

Gambar 1

\section{Hasil Pengujian Heteroskedastisitas}

Pada Gambar 2 terlihat sebaran titik variance yang membentuk masing masing 
variabel telah menyebar secara tidak merata serta tidak membentuk pola yang jelas sehingga terbebas dari gejala heteroskedastisitas. Oleh sebab itu proses pengolahan data lebih lanjut dapat dilaksanakan.

\section{Pengujian Hipotesis}

Berdasarkan hasil pengujian hipotesis yang telah dilakukan diperoleh ringkasan hasil terlihat pada Tabel 5 di bawah ini:

Tabel 5

Hasil Pengujian t-Statistik

\begin{tabular}{|c|c|c|c|}
\hline Keterangan & Sig & Std & Hasil \\
\hline Keseimbangan Kehidupan Kerja & 0.011 & 0.05 & Diterima \\
\hline Kepribadian Proaktif & 0.942 & 0.05 & Ditolak \\
\hline Kecerdasan Emosional & 0.004 & 0.05 & Diterima \\
\hline
\end{tabular}

Sumber: data diolah (2019)

Berdasarkan hasil pengolahan data diperoleh nilai koefisien determinasi sebesar 0.531 . Nilai koefisien tersebut menunjukan bahwa keseimbangan kehidupan kerja, kepribadian proaktif dan kecerdasan emosional mampu memberikan variasi kontribusi dalam memengaruhi perubahan kepuasan berkarir yang dirasakan pegawai Kantor Sekretariatan Kabupaten Pasaman sebesar $53.10 \%$, sedangkan $46.90 \%$ lagi dijelaskan oleh variabel lain.

Pada proses pengujian F-statistik terlihat nilai sig $0.000<0.05$ maka dapat disimpulkan bahwa keseimbangan kehidupan kerja, kepribadian proaktif, dan kecerdasan emosional merupakan variabel yang tepat untuk memprediksi perubahan kepuasan berkarir yang dirasakan pegawai Kantor Sekretariatan Kabupaten Pasaman.

Kemudian pada pengujian hipotesis pertama yang dilakukan dengan menggunakan uji t-statistik untuk variabel keseimbangan kehidupan kerja, diperoleh nilai sig sebesar 0.011 yang berada jauh dibawah 0.05 sehingga dapat disimpulkan keseimbangan kehidupan kerja berpengaruh signifikan terhadap kepuasan karir yang dirasakan pegawai Sekretariatan Kabupaten Pasaman. Hasil yang diperoleh menunjukan semakin baik keseimbangan pegawai dalam mengelola kewajiban dan tanggung jawab di dalam lingkungan instasi maupun lingkungan keluarga, maka akan semakin mendorong meningkatnya kepuasan karir yang dirasakan pegawai. Dengan demikian hipotesis pertama diterima.

Temuan yang diperoleh pada tahapan pengujian hipotesis pertama sejalan dengan hasil penelitian Karatepe, et. al. (2020) menemukan bahwa keseimbangan kehidupan kerja (work life balance) berpengaruh positif terhadap kepuasan dalam berkarir. Hasil yang sejalan juga diperoleh oleh Rondonuwu, et. al. (2018) menemukan bahwa keseimbangan kehidupan kerja berpengaruh positif terhadap kepuasan karir yang dirasakan karyawan Hotel Sintesa Penisula Menado. Selanjutnya, hasil penelitian yang sejalan juga diperoleh oleh Yusnani dan Prasetio, (2018) yang juga memperkuat hasil penelitian sebelumnya yang menyatakan keseimbangan kehidupan kerja berpengaruh positif terhadap kepuasan berkarir yang dirasakan karyawan.

Pada pengujian hipotesis kedua diperoleh nilai sig sebesar $0.942>0.005$. Proses pengolahan dilakukan, maka disimpulkan bahwa kepribadian proaktif tidak berpengaruh signifikan terhadap kepuasan karir yang dirasakan pegawai Sekretariatan Kabupaten Pasaman. Temuan yang diperoleh pada tahapan pengujian hipotesis kedua mengisyaratkan bahwa peningkatan kepuasan karir tidak cukup hanya didukung oleh kepribadian proaktif yang dimiliki setiap pegawai. Akan tetapi, kepuasan karir akan terwujud melalui perpaduan kepribadian proaktif dengan 
kemampuan dan pengalaman dalam bekerja. Dengan demikian hipotesis kedua ditolak.

Hasil yang diperoleh sejalan dengan teori yang dijelaskan oleh Luthans (2017) yang menyatakan bahwa kepuasan karir tidak saja dipengaruhi oleh faktor kepribadian akan tetapi juga dapat dipengaruhi oleh sejumlah variabel lainya seperti job engagement, job insecurity, dan sebagainya. Hasil penelitian yang sejalan juga diperoleh Li dan Yuan (2017) dan Ferreira, et. al. (2018) yang sama-sama menemukan bahwa proactive personality tidak berpengaruh signifikan terhadap kepuasan berkair yang dirasakan karyawan. Walaupun demikian kepuasan karir menjadi faktor penting yang akan membuat seorang karyawan bertahan dalam organisasi.

Pada pengujian hipotesis ketiga yang dilakukan melalui uji t-statistik diperoleh nilai sig sebesar $0.004<0.05$ maka dapat disimpulkan. kecerdasan emosional berpengaruh positif dan signifikan terhadap kepuasan karir yang dirasakan pegawai Sekretariatan Kabupaten Pasaman. Hasil yang diperoleh tersebut dapat dimaknai semakin tinggi kecerdasan emosional yang dimiliki seorang pegawai akan mendorong meningkatnya kepuasan karir yang mereka miliki. Dengan demikian hipotesis ketiga diterima.

Hasil yang diperoleh pada tahapan pengujian hipotesis ketiga sejalan dengan hasil penelitian Sultana, et. al. (2016) menemukan bahwa kecerdasan emosional berpengaruh positif terhadap kepuasan karir. Sony dan Mekoth (2016) menemukan bahwa kecerdasan emosional berpengaruh positif terhadap kepuasan berkarir pada pegawai perempuan. Kecerdasan emosional yang baik akan mendorong karyawan mudah untuk beradaptasi dan disenangi oleh rekan kerja maupun atasan. Sehingga ketika menghadapi pekerjaan yang sulit kerja sama yang terbentuk dengan rekan kerja ataupun atasan mampu diatasi menjadi sebuah prestasi yang dapat dibanggakan oleh karyawan. Selanjutnya hasil penelitian yang sejalan diperoleh Karatepe, et. al. (2020) yang menemukan bahwa kecerdasan emosional yang baik akan meningkatkan peluang kepuasan berkarir yang lebih tinggi.

\section{SIMPULAN DAN SARAN}

\section{Simpulan}

Sesuai dengan analisis dan pembahasan hasil pengujian hipotesis maka dapat diajukan simpulan penting yang merupakan jawaban dari permasalahan yang diajukan pada penelitian ini, yaitu keseimbangan kehidupan kerja berpengaruh signifikan terhadap kepuasan karir pada pegawai Kantor Kesekretariatan Kabupaten Pasaman.

Pada tahapan pengujian hipotesis kedua ditemukan bahwa kepribadian proaktif tidak berpengaruh signifikan terhadap kepuasan karir pada pegawai Kantor Kesekretariatan Kabupaten Pasaman, sedangkan pada tahapan pengujian hipotesis ketiga ditemukan bahwa kecerdasan emosional berpegaruh signifikan terhadap kepuasan karir pada pegawai Kantor Kesekretariatan Kabupaten Pasaman.

\section{Saran}

Sejalan dengan uraian kesimpulan maka diajukan beberapa saran yang dapat bermanfaat, yaitu: masih terdapatnya sejumlah metode yang lebih mutakhir yang dapat digunakan untuk membuktikan kebenaran hipotesis seperti menggunakan pendekatan Structural Equation Model (SEM) untuk membentuk model penelitian yang lebih akurat; masih terdapatnya model yang lebih mutahir dan diolah dengan menggunakan software yang lebih terbaru, 
seperti menggunakan analisis structural equation model melalui pengujian AMOS dan Listrel; adanya variabel lain yang berada diluar model mempengaruhi kepuasan karir yang dirasakan pegawai seperti yang terlihat dari R-square. Variabel tersebut meliputi kualitas kehidupan kerja, job engagement, perceived organizational support dan sebagainya

\section{DAFTAR PUSTAKA}

Buil, I., Martínez, E., \& Matute, J. (2019). Transformational leadership and employee performance: The role of identification, engagement and proactive personality. International Journal of Hospitality Management, 77(October 2017), 64-75. https://doi.org/10.1016/j.ijhm.2018.06.014

Chen, H., Richard, O. C., Dorian Boncoeur, O., \& Ford, D. L. (2020). Work engagement, emotional exhaustion, and counterproductive work behavior. Journal of Business Research, 114(April 2019), 30-41.

Ferreira, A. I., Cardoso, C., \& Braun, T. (2018). The mediating effects of ego-resilience in the relationship between organizational support and resistance to change. Baltic Journal of Management, 13(1), 104-124. https://doi.org/10.1108/BJM-06-2017-0171

Ismasari, D. (2016). Pengaruh Kepuasan Atas Kompensasi, Kepribadian Pro Aktif dan Lingkungan Organisasi Terhadap Kepuasan Kerja dengan Status Karyawan Sebagai Pemodarasi. Jurnal Manajemen Bisnis, 6(2).

James L Gibson, Johm M Ivancevich, J. H. D. J. \& R. K. (2015). Organizations Behavior, Structure, Processes (14th ed.). Irwin: McGraw-Hill.

Jawahar, I. M., \& Liu, Y. (2016). Proactive personality and citizenship performance: The mediating role of career satisfaction and the moderating role of political skill. Career Development International, 21(4), 378-401. https://doi.org/10.1108/CDI-022015-0022

Jean E. Wallace. (2015). Can Women in Law Have it All? A Study of Motherhood, Career Satisfaction and Life Balance.

\author{
International Encyclopedia of \\ Organization Studies, 24(9). \\ https://doi.org/10.4135/9781412956246.n4 \\ 48
}

Jensen, K. W., Liu, Y., \& Schøtt, T. (2017). Entrepreneurs innovation bringing job satisfaction, work-family balance, and life satisfaction: In China and around the world. International Journal of Innovation Studies, 1(4), 193-206.

Joo, B. K. (Brian), \& Ready, K. J. (2012). Career satisfaction: The influences of proactive personality, performance goal orientation, organizational learning culture, and leader-member exchange quality. Career Development International, 17(3), 276-295.

Judge, Stevem. P. Robbin. \& Timothy. A. (2016). Organizational Behavior (15e ed.). Irwin: McGraw-Hill.

Karatepe, O. M., Rezapouraghdam, H., \& Hassannia, R. (2020). Job insecurity, work engagement and their effects on hotel employees' non-green and nonattendance behaviors. International Journal of Hospitality Management, 87(April 2019), 102472.

Li, J., \& Yuan, B. (2017). Both angel and devil: The suppressing effect of transformational leadership on proactive employee's career satisfaction. International Journal of Hospitality Management, 65, 59-70. https://doi.org/10.1016/j.ijhm.2017.06.008

Luthans, F. (2017). Organizational Behavior: Organizational Contexts. Contexts (13th ed.). Irwin: McGraw-Hill.

Neumann, J. L., Mau, L. W., Virani, S., Denzen, E. M., Boyle, D. A., Boyle, N. J., ... Burns, L. J. (2018). Burnout, Moral Distress, Work-Life Balance, and Career Satisfaction among Hematopoietic Cell Transplantation Professionals. Biology of Blood and Marrow Transplantation, 24(4), 849-860.

Qodrizana, D. L., \& Musadieq, M. Al. (2018). Pengaruh Work-Life Balance Terhadap Kepuasan Kerja (Studi Pada Karyawan Perempuan Yayasan Insan Permata Tunggulwulung Kota Malang). Jurnal Administrasi Bisnis, 60(1), 9-17.

Rivai, V. \& E. J. S. (2016). Manajemen Sumber 
Daya Manusia Untuk Perusahaan: Dari Teori Ke Praktik (Edisi 3). Jakarta: Rajawali Pers.

Rondonuwu, F., Rumawas, W., \& Asaloei, S. (2018). Pengaruh Work-life Balance Terhadap Kepuasan Kerja Karyawan Pada Hotel Sintesa Peninsula Manado. Jurnal Administrasi Bisnis, 7(2), 30-39. https://doi.org/10.35797/jab.7.2.2018.2204 4.30-39

Sony, M., \& Mekoth, N. (2016). The relationship between emotional intelligence, frontline employee adaptability, job satisfaction and job performance. Journal of Retailing and Consumer Services, 30, 20-32.

Srikanth, A. P. B., \& Israel, D. (2012). Career Commitment \& Career Success : Mediating Role of Career Satisfaction. Indian Journal of Industrial Relations, 48(1), 137-149.

Sultana, R., Yousaf, A., Khan, I., \& Saeed, A. (2016). Probing the interactive effects of career commitment and emotional intelligence on perceived objective/subjective career success. Personnel Review, 45(4), 724-742.
Suryanti, E. (2019). Pengaruh Kecerdasan Emosional Terhadap Kepuasan Karir Melalui Keterampilan Politik. Jurnal Riset Manajemen Sains Indonesia (JRMSI), 10(2), 86-97.

Trivellas, P., Kakkos, N., Blanas, N., \& Santouridis, I. (2015). The Impact of Career Satisfaction on Job Performance in Accounting Firms. The Mediating Effect of General Competencies. Procedia Economics and Finance, 33(15), 468-476.

Valentine, S., Godkin, L., Fleischman, G. M., Kidwell, R. E., \& Page, K. (2015). The Mediating Role of Career Satisfaction. Journal of Business Ethics, 101(4), 509523. https://doi.org/10.1007/s10551-01

Yusnani, E., \& Prasetio, A. P. (2018). Kontribusi Work Life Balance terhadap Job Satisfaction pada Karyawan Dinas Koperasi dan Usaha Kecil. Jurnal Penelitian Pendidikan, 18(2), 135-143. https://doi.org/10.17509/jpp.v18i2.12954 